DOI https://doi.org/10.30525/978-9934-26-182-4-15

\title{
ASSESSMENT OF THE QUALITY OF LIFE ACCORDING OF THE SF-36 QUESTIONNAIRE IN ADOLESCENTS WITH PRIMARY HYPERTENSION
}

\author{
Patsera M. V. \\ Candidate of Medical Sciences, \\ Associate Professor at the Department of Propaedeutics \\ of Children's Diseases \\ Propaedeutics of children's diseases \\ Zaporizhzhia State Medical University
}

Tovma A. V.

Candidate of Medical Sciences,

Assistant at the Department of Propaedeutics of Children's Diseases,

Propaedeutics of children's diseases

Zaporizhzhia State Medical University

Skrypnykova Ya.S.

Assistant at the Department of Propaedeutics of Children's Diseases

Propaedeutics of children's diseases

Zaporizhzhia State Medical University

Zaporizhzhia, Ukraine

Introduction. The priority area in the study of the etiological factors of arterial hypertension (AH) is genetic research. Single nucleotide polymorphisms (SNPs) of genes of the NFATC (nuclear factor of activated Tcells) family do not directly affect blood pressure (BP) in humans but can participate in the formation of an unfavorable course of AH. Among the most important SNPs of the NFATC4 gene, rs2229309 (Gly160Ala), which affects the development of cardiac hypertrophy, can be noted [1, P. 435]. Previously, we have established the prevalence of the occurrence of the G rs2229309 allele of the NFATC4 gene in the genotypes of adolescents with primary AH, with early formation of left ventricular hypertrophy. Further research aimed at phenotyping variations in the NFATC genes could be promising for the future study of the pathogenesis and clinical manifestations of AH in young people. Modern approaches to assessing the quality of life $(\mathrm{QoL})$ represent a clinical approach to identifying disorders of the patient's health status by analyzing the system of signs that make up the concept of general health. By studying the QoL 
indicators, it is possible to determine rational approaches to the treatment of the disease and evaluate their results in dynamics, according to the indicators obtained on the basis of the subjective feelings of the patient themself.

Research objective: to determine the associations of the variability of the NFATC1 and NFATC4 genes with the QoL assessments based on the results of the SF-36 questionnaire in adolescents with primary AH.

Examination materials and methods. An informed consent of the patients and their parents was obtained for the examination. The object of the study was adolescents aged 16-18 years, whose BP was measured according to the office method during routine examinations [2, P. 72]. Based on clinical guidelines for the management of high BP in children and adolescents, BP values $\geq 120 / 80$ $\mathrm{mm} \mathrm{Hg}$ represent an indicator of the screening risk for the presence of $\mathrm{AH}$ [3, P. 1889]. Based on several subsequent measurements of BP with an interval of one to two weeks, 124 adolescents with a probable diagnosis of $\mathrm{AH}$ were selected, in which at least 2 measurements of office BP were in the range of 130-160 mm Hg systolic (SBP) and/or 80-100 mm Hg diastolic BP (DBP). In order to verify $\mathrm{AH}$, determined on the basis of office measurements of $\mathrm{BP}$, all adolescents underwent ambulatory BP monitoring (ABPM) using the CardioTens device (Meditech Ltd, Hungary). The results of ABPM were evaluated according to the recommendations of the European Society of Hypertension [4, P. 684]. Further examination plan included general clinical and additional instrumental research methods (electrocardiography, echocardioscopy, ophthalmoscopy, ultrasound examination of the kidneys, adrenal glands, and thyroid gland) aimed at excluding symptomatic (secondary) AH. As a result, 84 adolescents were selected ( 60 boys and 24 girls). The control group consisted of 20 adolescents with normal BP values in accordance with gender, age, and height. At the beginning of the study and after 2 years, all adolescents were surveyed using the Medical Outcomes Study Questionnaire Short Form 36 Health Survey (SF-36). A characteristic feature of this study was the repeated survey among the adolescents (aged 16 and 18 years), which, according to D. Edvardsson, has the potential to increase the overall relevance of the survey [5, P. 3]. The results were calculated using an electronic test program for assessing QoL according to the SF-36 method via a direct questionnaire. A molecular genetic study of the polymorphisms of the NFATC1 and NFATC4 genes via the real-time polymerase chain reaction method according to the manufacturer's instructions (Applied Biosystems, USA) was a mandatory step. Genotyping was performed using TaqMan probes and TaqMan ${ }^{\circledR}$ SNP Genotyping Assays (Applied Biosystems $^{\mathrm{TM}}$ ) on a CFX96TM Real-Time PCRDetection Systems amplificator (Bio-Rad Laboratories, Inc., USA). Statistical analysis of PCR data was performed using CFX Manager ${ }^{\mathrm{TM}}$ software (Bio-Rad, USA). 
The examination results were processed using medical statistics with the Statistica 10 software (StatSoft, Inc., USA).

Results and discussion. Analysis of the results of the questionnaire survey among adolescents with primary $\mathrm{AH}$ and patients in the control group showed that almost all indicators of the SF-36 questionnaire, regardless of whether they were obtained at the age of 16 or 18 years, virtually did not differ in both boys and girls. The data obtained allowed to combine and average out the indicators of the twice questionnaires and use them in further statistical modeling. Molecular genetic studies of the variability of the NFATC1 and NFATC4 genes allowed to investigate the possibility of their association with the results of QoL assessments. Low self-assessments of QoL were revealed in adolescents with AH, who were also carriers of the TT rs11665469 genotype of the NFATC1 gene, which formed a general QoL deficit in this subpopulation, as expressed by the lowest total QoL indicator in comparison with all studied genotypes (600 \pm 60 out of 800 maximum possible points of the SF-36 questionnaire).

Conclusions. We have established an association of the TT rs11665469 NFATC1 genotype with the low self-assessment of the QoL of its carriers. The polymorphism of genotypes of the NFATC family affects the course of AH, forming a complex of medical and social disorders of the state of health, worsens the state of health, which ultimately can compromise mental and social adaptation, leading to asthenoneurotic and depressive states. The revealed patterns can be used in assessing the severity of the course of the disease.

\section{References:}

1. Половкова О. Г., Макеева О. А., Гончарова И. А. и др. Профили экспрессии генов пути кальциневрина в миокарде в связи с ремоделированием ишемического сердца у людей. Молекулярная биология. 2013. № 47 (3). C. 433-440. DOI: 10.7868 / S0026898413030117.

2. Ivanko O.H., Patsera M.V., Tovma A.V., Skrypnykova Y.S. Justification of the application of physical therapy in youth with arterial hypertension. Abstracts of International scientific and practical conference «Medicine and health care in modern society: topical issues and current aspects» : Conference proceedings, February 26-27, 2021. Lublin, Republic of Poland : «Baltija Publishing», 2021. 240 pages. P. 71-74. DOI: 10.30525/978-9934-26-038-4-18.

3. Flynn J. T., Falkner B. E. New Clinical Practice Guideline for the Management of High Blood Pressure in Children and Adolescents. Hypertension. 2017. Vol. 70, № 4. P. 683-686. DOI:10.1161/ HYPERTENSIONAHA.117.10050

4. Lurbe E., Agabiti-Rosei E., Cruickshank J. K., et al. 2016 European Society of Hypertension guidelines for the management of high blood pressure 
in children and adolescents. J Hypertens. 2016. № 34 (10). P. 1887-920. DOI: 10.1097/HJH.0000000000001039.

5. Edvardsson D., Baxter R., Corneliusson L. Advancing Long-Term Care Science Through Using Common Data Elements: Candidate Measures for Care Outcomes of Personhood, WellBeing, and Quality of Life. Gerontology \& Geriatric Medicine. 2019. Vol. 5, P. 1-15. DOI: 10.1177/2333721419842672.

DOI https://doi.org/10.30525/978-9934-26-182-4-16

\title{
ПОШКОДЖЕННЯ НЕЙРОНІВ ПРИ ПЕЧІНКОВІЙ ЕНЦЕФАЛОПАТІЇ
}

\author{
Рафальська Н. С. \\ заочний аспірант кафедри неврології \\ Харківський національний медичний університет \\ Товажнянська О. Л. \\ доктор медичних наук, професор, \\ завідувачка кафедри неврології \\ Харківський наиіональний медичний університет \\ Марковська О. В. \\ кандидат медичних наук, \\ доцент кафедри неврології \\ Харківський національний медичний університет \\ м. Харків, Україна
}

Печінкова енцефалопатія (ПЕ) - часте ускладнення та один 3 найважчих проявів захворювань печінки, що значно ускладнює життя пацієнтів та погіршує якість їхнього життя. ПЕ розвивається на тлі багатьох відомих гострих і хронічних захворювань печінки, таких як вірусний гепатит, токсичний гепатит, хронічний активний гепатит, обтурація жовчних шляхів, цироз печінки та ін. [1,2]. Клінічна картина ПЕ представлена широким спектром неспецифічних неврологічних та психіатричних проявів, тяжкість яких прогресуюче наростає від мінімального ступеня до тяжкого ступеня згідно з критеріями West-Haven. При латентній ПЕ клінічна картина мінімальна, а достовірно змінюються лише результати психометричних тестів та електрофізіологічних 64 